\title{
Productivity Improvement and Zero Defect in Diff Case Sub Assy Line
}

\author{
M. Kumaran, V. Kandeeban, T. Premkumar
}

\begin{abstract}
The Differential case is considered as the very critical assembly and it plays very important role in power distribution to the both axles i.e. $\mathrm{LH}$ axle housing and $\mathrm{RH}$ axle housing. In this assembly line there is lot of internal quality issues and bottlenecking areas, this leads to pulling down the overall productivity and Right at First time. Hence I take this as a project to improve the productivity and to reduce quality defects to zero. Here I used the tool as lean principles of eliminating the waste for productivity improvement and six sigma tool for quality improvements. This two are the highly efficient tool which is used nowadays for all the analysis.
\end{abstract}

\section{INTRODUCTION}

In TAFE organization we follow lean principles in a major role. Based on this unique practice we the team implement all the improvements in the plant. This Lean tool used to reduce the waste in the whole plant in terms of OLE and OEE. OLE is Overall equipment Effectives and OEE is Overall equipment Efficiency.

\section{PLEAN FOR PRODUCTOION AND SERVICES}

In TAFE we follow all the improvements in the system of Lean tool, As the advanced process of Six sigma tool. Lean and six sigma focused to reduce the waste in all cells like rear transmission and transmission case and Chassis assembly and Post painting stage.

\section{SEVEN TYPES OF WASTES}

In our Factory, the seven wastes are captured in a systematic way of approach by using standard principles.

\section{A. T- Transportation}

Transportation waste leads to more distance for transportation of material. In this project the material movement from stores to assembly line take more time, here we take special initiation to reduce the distance.

\section{B. I - Inventory}

Inventory more inventory leads to wastage of money

Revised Manuscript Received on December 16, 2019.

* Correspondence Author

T. Premkumar *, department of Mechanical Engineering, Kalasalingam Academy of Research \& Education, Virudhunagar Dist., Tamilnadu, India. Email: t.premkumar@klu.ac.in

M. Kumaran , department of Mechanical Engineering, Kalasalingam Academy of Research \& Education, Virudhunagar Dist., Tamilnadu, India. Email: kumaran.vmp@gmail.com

V. Kandeeban, department of Quality Assurance, Tractor and Farm Equipment (TAFE) Ltd., Kalladipatti - 624201, Dindigul Dist, Tamilnadu, India.Email: Kandeebanv@tafe.com in the plant. In this project the current practice is holding inventory of ten tractors in every area. These parts are supplied as batch and stored as bulk. Hence this requires more inventory and inventory cost also very high. We take a special initiatives like kitting supply to the sub assembly and then to the main line. This process considerably reduced the line side inventory and inventory cost.

\section{M-Motion waste}

More cycle time leads to the increase in operating cost and leads to reduction in productivity. Here in the diff case assembly line assy line all the parts are placed around two meters away from the operator. Hence the operator has to move more distance from the work place, we focused to reduce the operator motion by implementation the point of usage concept. This will be briefly described as following chapter.

\section{W-Waiting waste}

In the diff case assembly process the operator has to wait for the machine for the further planetary gears assembly operation. Because the machine time is very high about ninety five seconds, this leads to the major bottleneck for the operation. For that the machine reduced and balanced with the man time by implementing some improvements, that will described in the below title.

\section{E. O-Over processing}

In cell 1 assembly process, there may more non value added activities carried out to complete the assembly operation. Hence the flow diagram concept is implemented in the assy line, so that non value added activities are converted in to value added activities.

\section{F. O-Over production}

Producing components or parts more than the required quantity is leads waste of investment, it comes under seven waste category. Here in TAFE we control the production by optimized way.

\section{G. D-Rework and Defect waste}

More cycle time leads to the rework and scraping of components. If there is defect in the rear transmission assembly, it takes more time for rectification, because for that the entire tractor has to dismantled and do the correction in the part. Hence this is considered as a much critical process for tractor assembly, we take much more concentration on this process.

\section{Published By:}






\section{Productivity Improvement and Zero Defect in Diff Case Sub Assy Line}

\section{PROBLEM DEFINITION}

The problem definition is the chapter, where the description of the problem is given in detailed manner. The brief

Table 1.1-description of the problem

\begin{tabular}{|c|c|c|c|c|c|c|c|c|c|}
\hline \multirow[b]{2}{*}{ Sl.no } & \multirow{2}{*}{$\begin{array}{l}\text { Critical } \\
\text { Process - } \\
\text { Cell 123 } \\
\end{array}$} & \multicolumn{4}{|c|}{$\begin{array}{l}\text { Internal complaints } \\
\text { (Aug'13 to May'14) }\end{array}$} & \multicolumn{2}{|c|}{$\begin{array}{c}\text { External } \\
\text { complaints }\end{array}$} & \multirow{2}{*}{$\begin{array}{l}\text { Total } \\
\text { Defects } \\
\end{array}$} & \multirow{2}{*}{$\begin{array}{l}\text { 6Sigma } \\
\text { Level } \\
\text { (PPM) } \\
\end{array}$} \\
\hline & & CQA & CRA & YARD & Sick & PDI & DEPOT & & \\
\hline 1 & $\begin{array}{c}\text { Cell } 1 \text { - } \\
\text { Diffcase, } \\
\text { Pinion sub } \\
\text { \& R.T main } \\
\text { assembly }\end{array}$ & 0 & 0 & 0 & 38 & 0 & 0 & 38 & $\begin{array}{c}1488 \\
\text { PPM - } \\
\text { Internal } \\
\text { NC } \\
\end{array}$ \\
\hline 2 & $\begin{array}{l}\text { IDB sub } \\
\text { assembly }\end{array}$ & 0 & 0 & 0 & 0 & 0 & 0 & 0 & 0 \\
\hline 3 & $\begin{array}{l}\text { Hydraulic } \\
\text { setting }\end{array}$ & 7 & 0 & 0 & & 15 & 3 & 28 & 2268 \\
\hline 4 & $\begin{array}{l}\text { Housing } \\
\text { main drive } \\
\text { sub \& main } \\
\text { assembly }\end{array}$ & 5 & 1 & 1 & & 5 & 0 & 12 & 972 \\
\hline 5 & $\begin{array}{c}\text { Hub front } \\
\text { wheel } \\
\text { pre-loading }\end{array}$ & 0 & 0 & 0 & & 3 & 0 & 3 & 243 \\
\hline 6 & $\begin{array}{l}\text { PTO Sub } \\
\text { assy }\end{array}$ & 0 & 0 & 0 & & 4 & 0 & 4 & 324 \\
\hline 7 & $\begin{array}{c}\text { OIB Sub } \\
\text { assy }\end{array}$ & 0 & 0 & 0 & & 0 & 0 & 0 & 0 \\
\hline
\end{tabular}

heart of Tractor assembly process. Hence this project is reduce the PPM level and to achieve 6 sigma in parallel productivity also increased.

Table 1.2-process failure mode effect analysis

In diff case assembly line the PPM is level is 1388PPM with

introductions of the problem with some details are to be provided the table format. . 


\section{ANALYSIS}

\section{A. PFMEA}

Here in this project to find the potential failure in the process, we did a detailed analysis on the failure and its mode. Which is explained detailed in the below table. causes and effects for the process, hence to analysis this we need the chart it is done in two levels, Here We show the detailed level 2 chart for ease of understanding. This fish bone shows the linkage between all the factors like man, method and machine and environment related issues.

\section{B. Cause and Effect chart}

For the diff case assembly process there may more number of

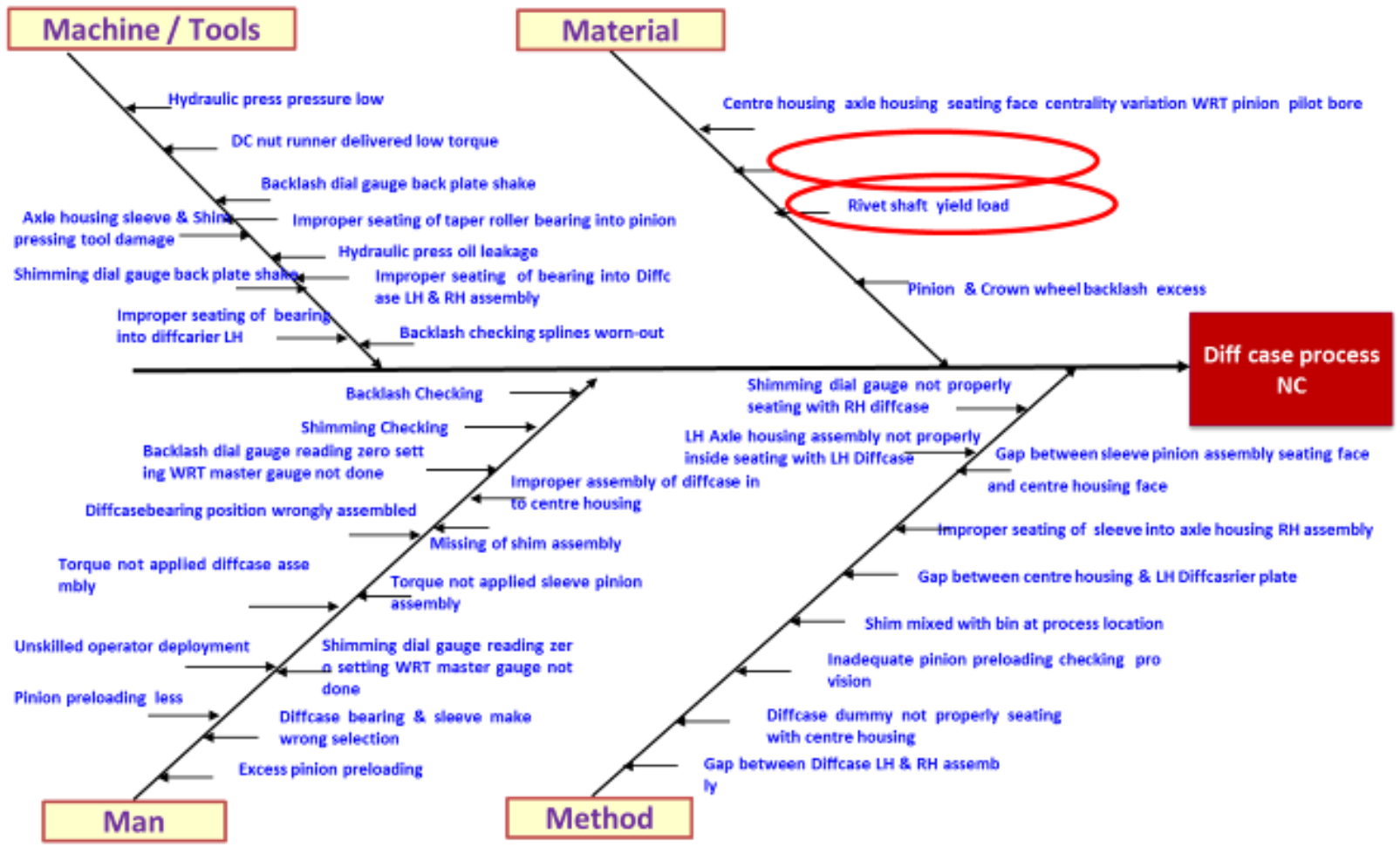

Fig1.1- Causes and effects

\section{Prioritized Causes for the defects}

In this project, the causes and the measures and the measures are done by using the Japanese technology as below.

Table 1.3- causes and effects

\begin{tabular}{|c|c|c|}
\hline S. No & Causes & Measures \\
\hline \multicolumn{3}{|l|}{1} \\
\hline 2 & Difficult in tightening of minus bolt & No foxture avaiable \\
\hline 3 & Diffioult in torque fer minus belts & Na proper halding asailable \\
\hline 4 & Cross shaft mismatching & Similar parts \\
\hline 5 & Cosper washer missine & Child parts \\
\hline 6 & Missing of terque for bolts & Human etrot \\
\hline 7 & Mare cysle time & 1248 secs far cne cyde \\
\hline 8 & Operator latigue high & Handling of weightedparts \\
\hline
\end{tabular}

D. Process analysis between old and new

The difference in process assembly between old and the new process are explained by using the exploded view as below and the difference for the two process also explained clearly in the below diagram. 
Productivity Improvement and Zero Defect in Diff Case Sub Assy Line

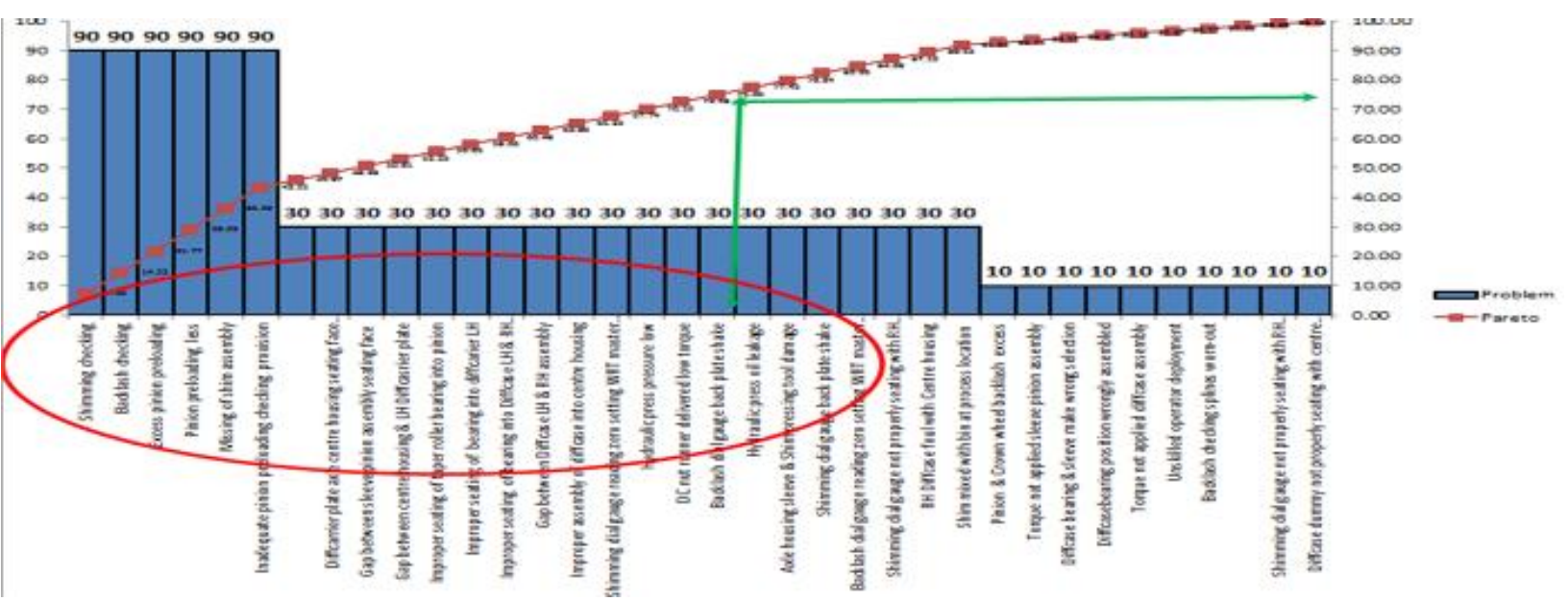

Fig. 1.3 Difference in process sequence

1. Backlash checking method

\section{DIFFERENCE IN PROCESS SEQUENCE}
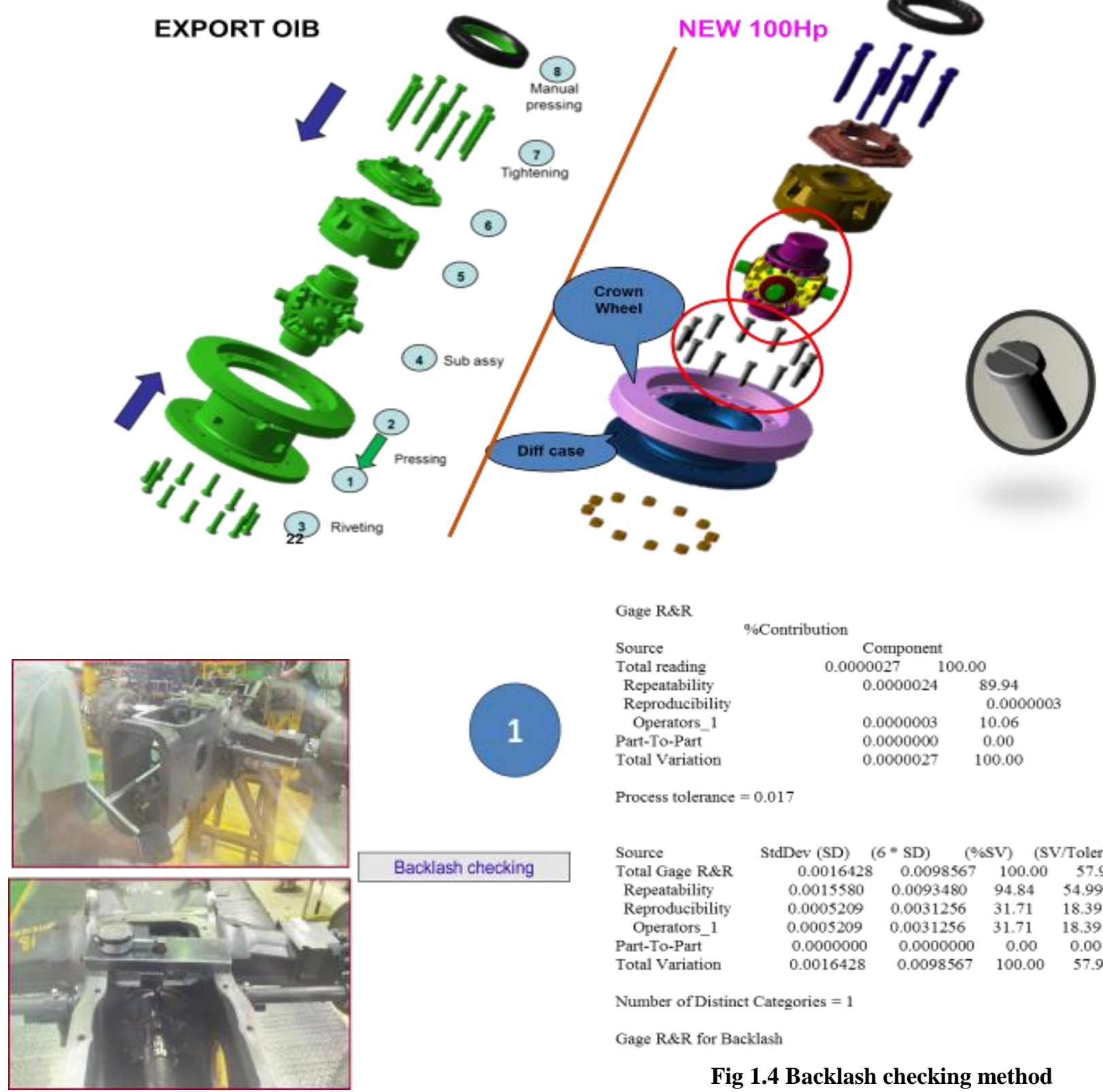

Gage R\&R

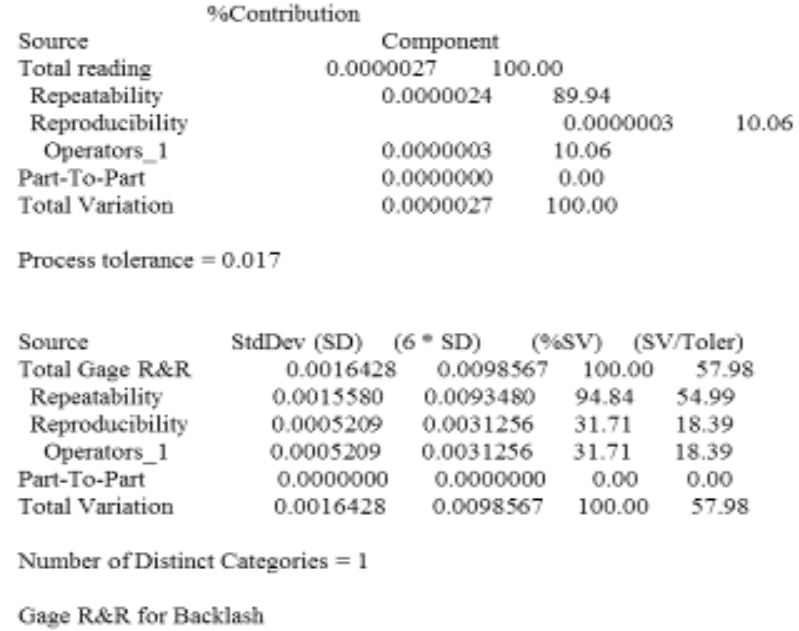

Fig 1.4 Backlash checking method

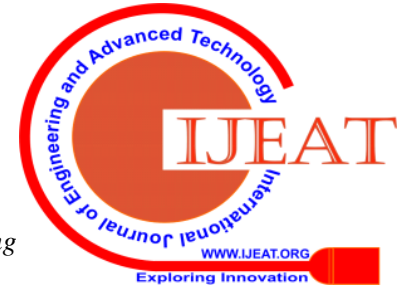




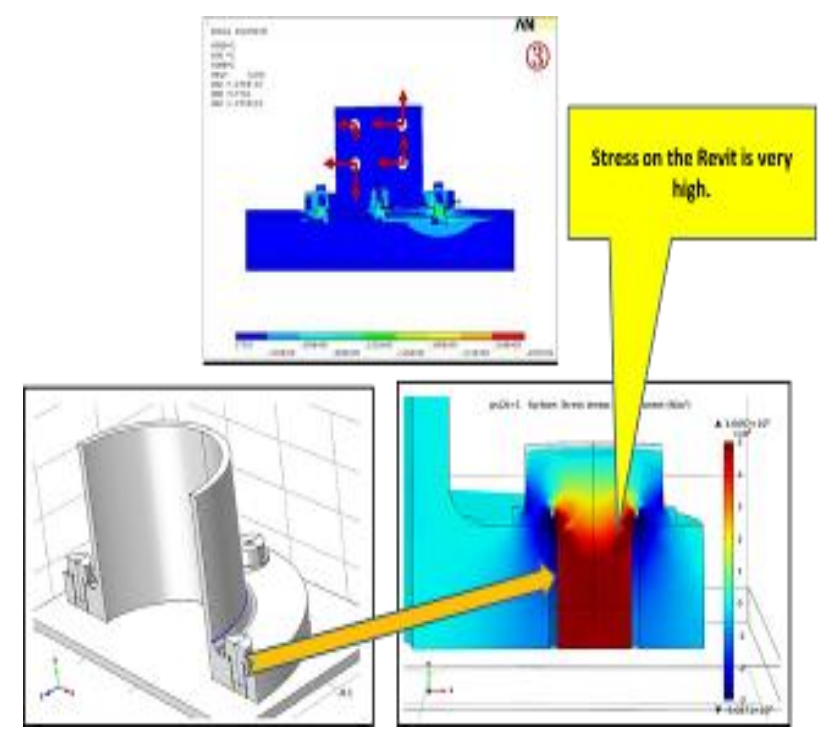

Fig 1.5 Anova

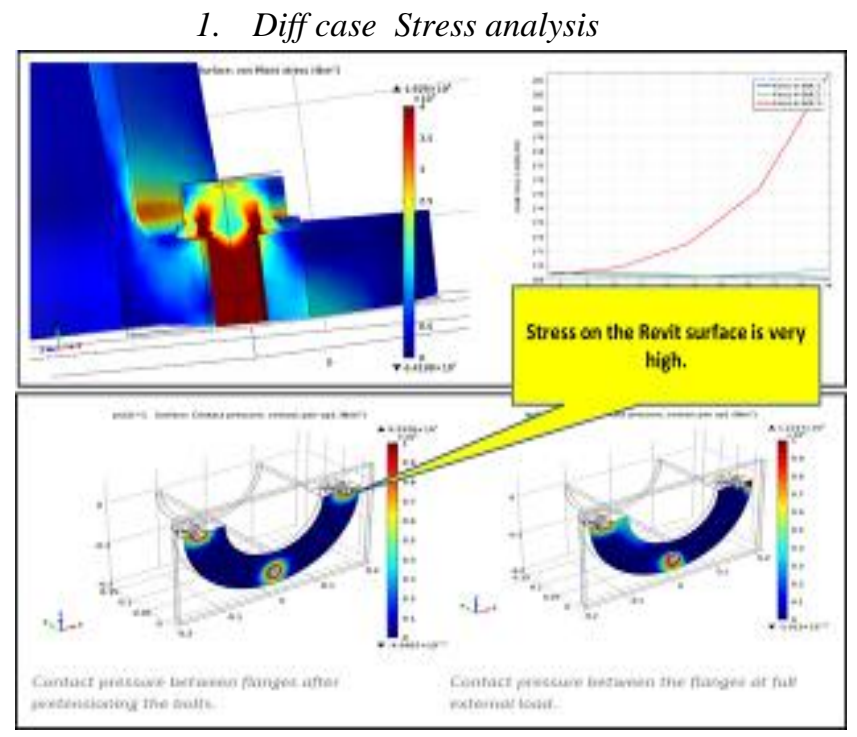

Fig 1.6 Stress analysis

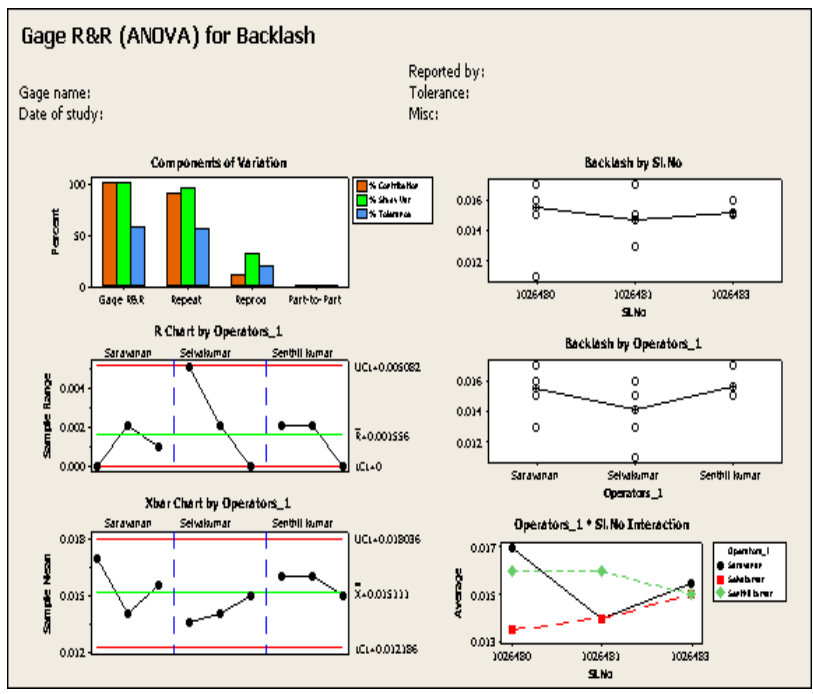

Fig 1.7 Stress analysis

2. Planetary gear stress analysis

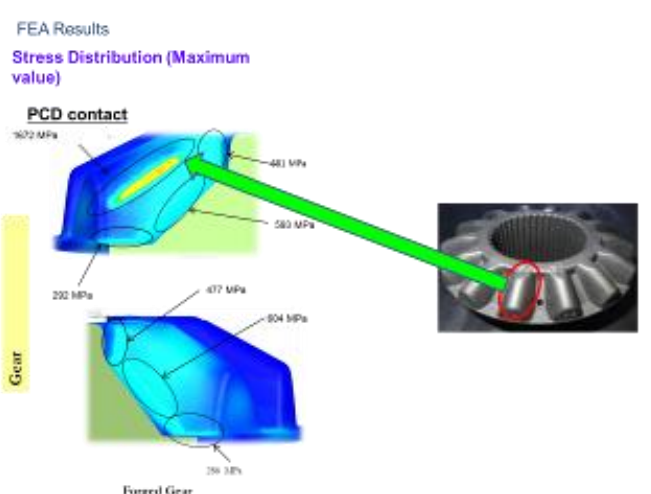

Fig 1.8 Stress distribution FEA study

Stress Distribution (Maximum value)
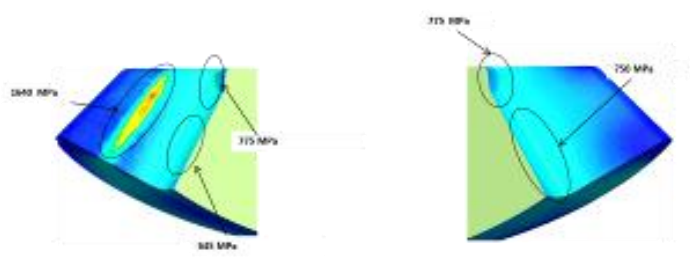

Fig 1.9 Stress distribution

\section{E. Actions taken for causes}

The main actions taken to avoid the cause one and two as detailed explain below.

\section{Diff case improvement}

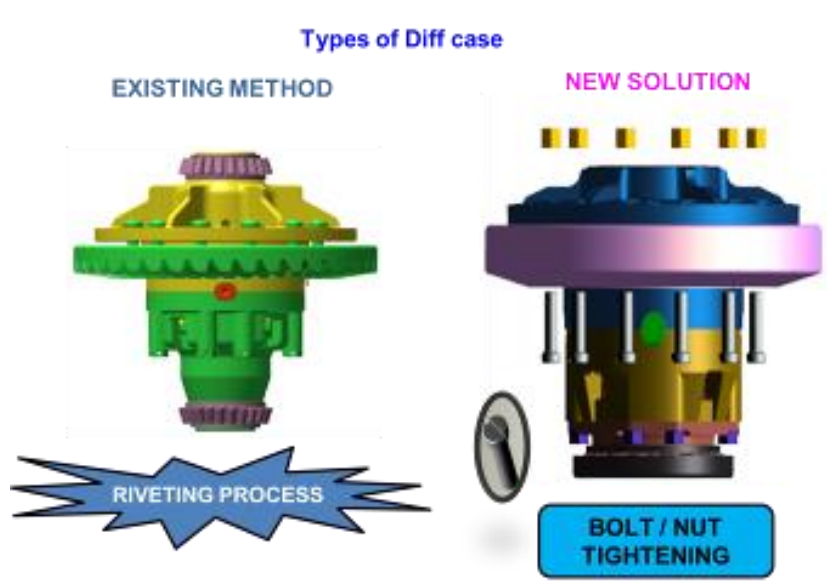

Fig 1.10 Type of diff case 
Productivity Improvement and Zero Defect in Diff Case Sub Assy Line

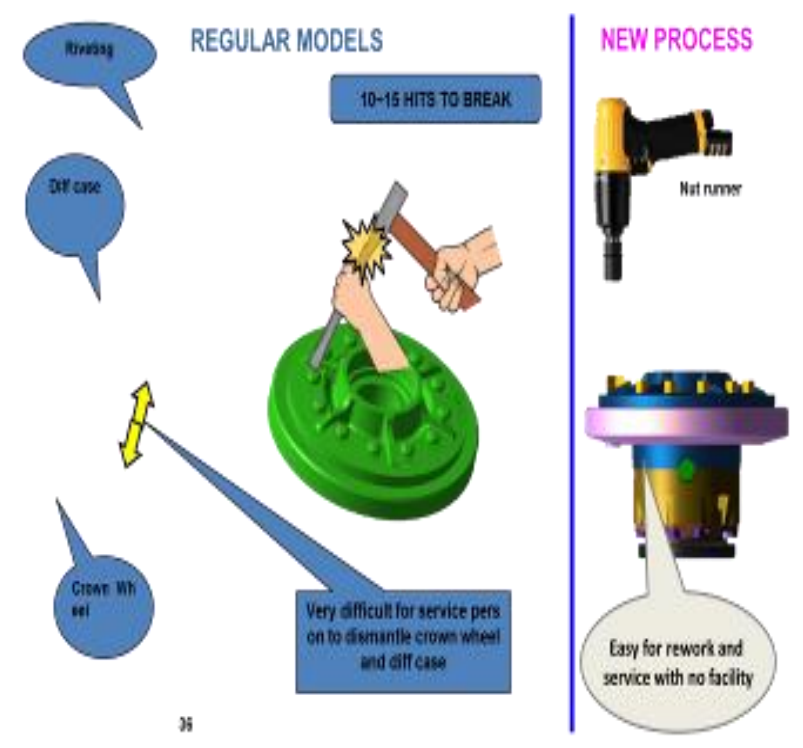

Fig 1.11 Models CURRENT CONDTION



Fig 1.12 Current condition

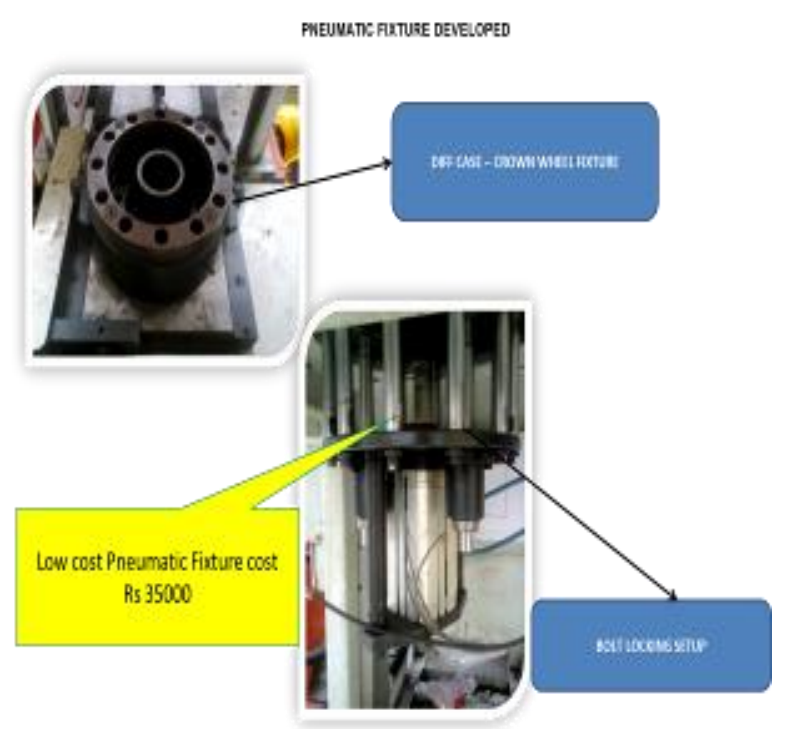

Fig 1.13 Pneumatic developed

2. Planetary gear design improvement

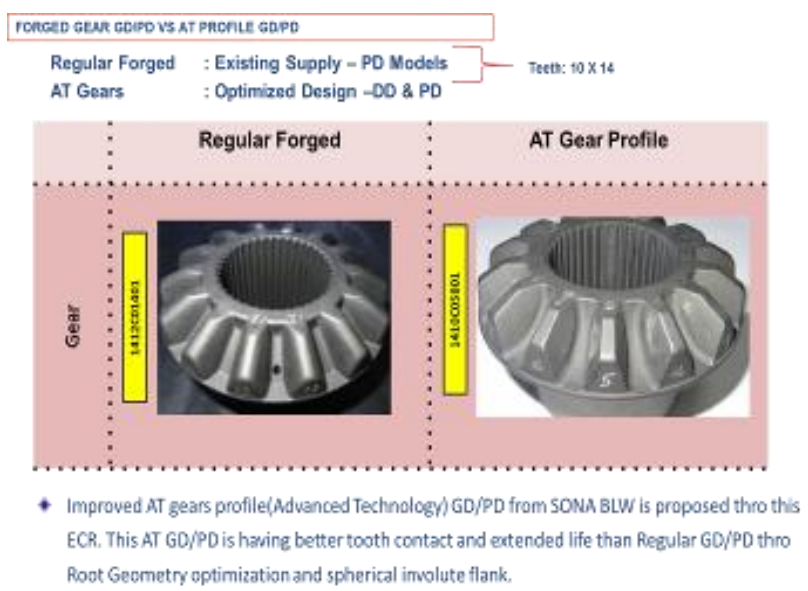

Fig 5.10 Improved designs

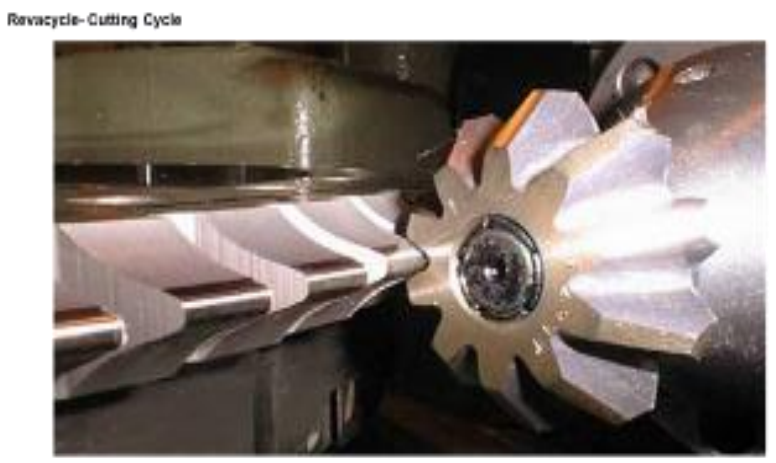

Broaching of a differential gear with Revacycle

Automotive differential gears are generally Gleason Revacycle designs.

Revacycle gears are cut by a large circular broach, which is extremely productive

Note : Knowledge got from Advanced machining technology paper - Fourth semester

\section{Fig 1.14 Cutting cycle}

\section{F. Testing results for improvements}

Here I have shown the testing results for all the improvements with the test report from FEA and stress analysis.

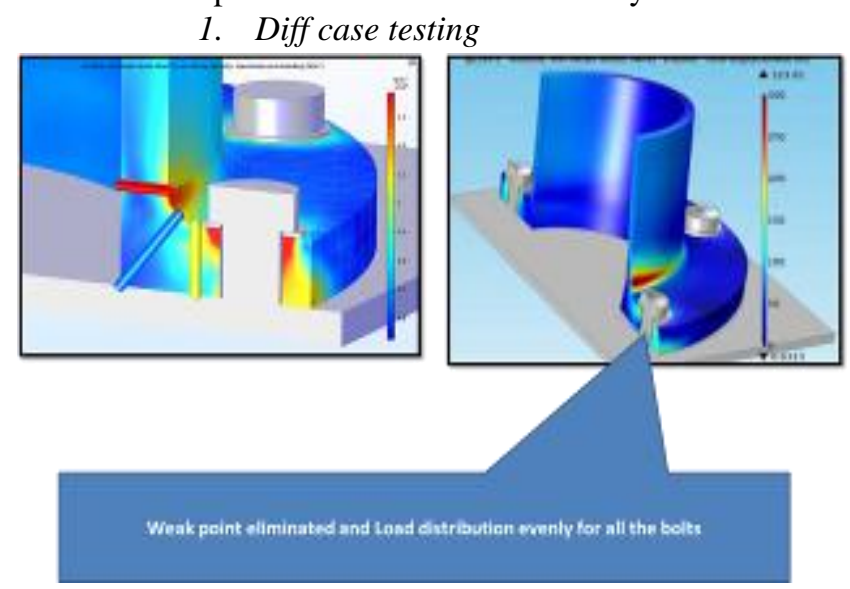

Fig 1.15 Test result

2. Planetary gear testing

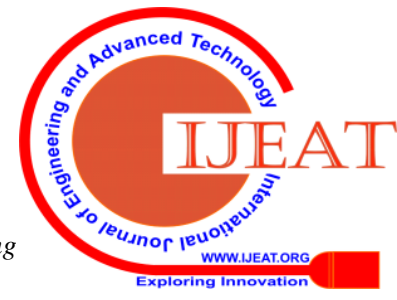


Testing condition and Results

Testing condition :

\begin{tabular}{|c|c|}
\hline Mode of vesing & 2+Aoser worfiguration \\
\hline Torquen Km leostsare] & $100 \mathrm{Nm}$ \\
\hline nFM & 25 \\
\hline
\end{tabular}

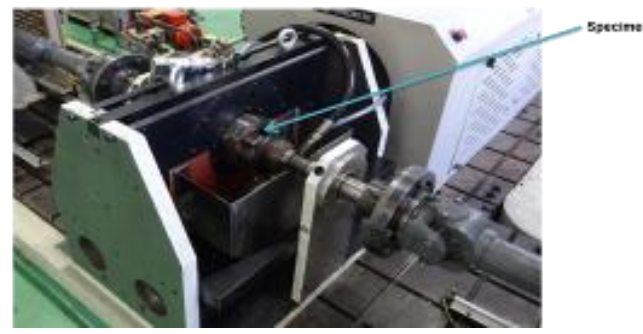

Fig 1.16 Testing condition

Durability Test Results and Comparison

\begin{tabular}{|c|c|c|c|}
\hline & & Non AT -Fored & AT" Fortod \\
\hline \multirow{3}{*}{ Ute $(\mathrm{Hes})$} & Sarrale 1 & 9 & 20 \\
\hline & 5ample 2 & 10 & 25 \\
\hline & Sample 3 & 12 & 26 \\
\hline \multicolumn{2}{|c|}{ Material } & aunters & anonos \\
\hline
\end{tabular}

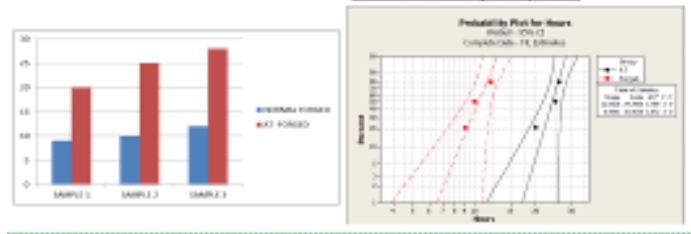

Fig 1.17 Durability test results and comparison

\section{TEST REPORT FOR AXLE SHAFT SPLINE}

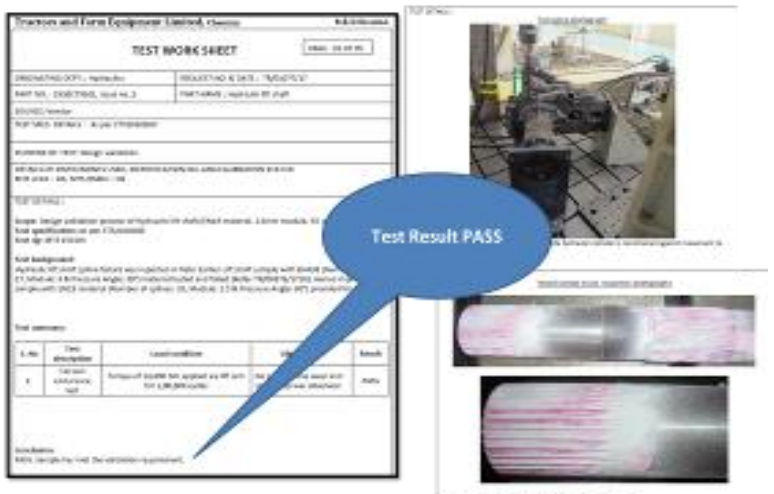

Nole : K-owlotge got from weiding and testing paper - Fifth semester

Fig 1.18 Test report for axle shaft spline

\section{G. Other Improvements done in line}

Diffcase washing - Stainless steel washing tray with partition

\begin{tabular}{|c|c|}
\hline Before & \\
\hline $\begin{array}{l}\text { Mild steel washing tray without parti } \\
\text { tion - Poor diffcase washing }\end{array}$ & $\begin{array}{l}\text { Stainless steel washing tray with } p \\
\text { artition introduced to improve the di } \\
\text { ficase washing }\end{array}$ \\
\hline
\end{tabular}

Fig 1.19 Diffcase washing - stainless steel washing tray

Nylon with rubber sheet for sleeve pinion assembly table

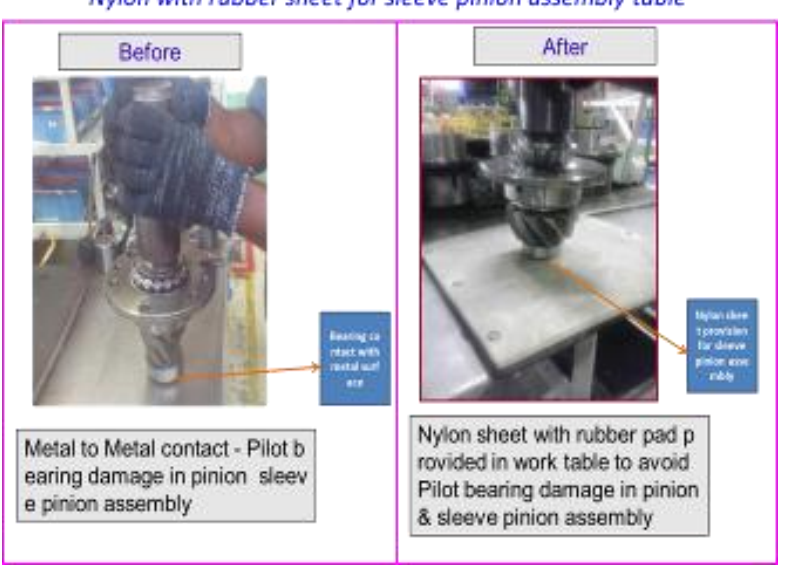

Fig 1.20 Nylon with rubber sheet for sleeve pinion assembly

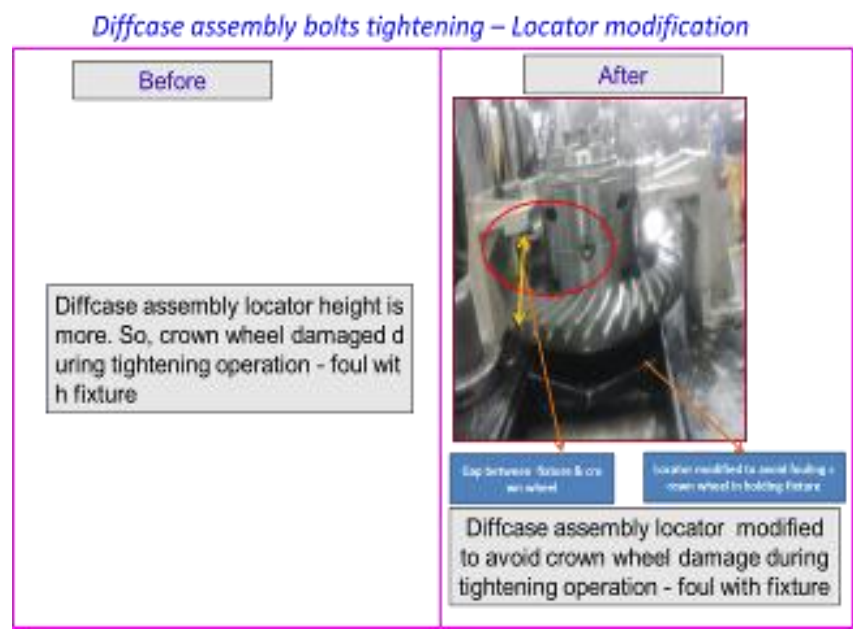

Fig 1.21 Diffcase assembly

\section{RESULTS AND BENEFITS}

In diff case assembly line the overall PPM, should down to $60 \mathrm{PPM}$ as shown in the below graph. Here from the past financial year the parts per million is 1488 and by implementing all the improvements in quality by implementing poka yoke in the line PPM come down.

$$
\text { Diff case quality defects PPM Trend }
$$

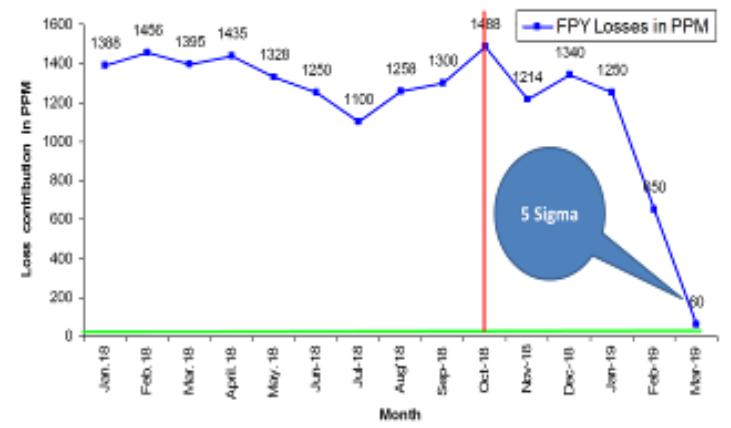

Fig 6.1 Diff case assembly line the overall PPM

Published By:

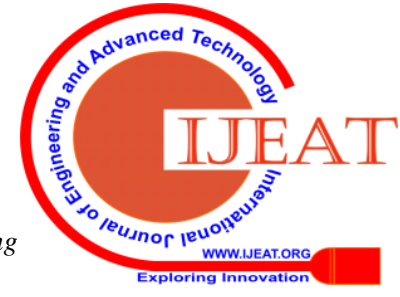




\section{Productivity Improvement and Zero Defect in Diff Case Sub Assy Line}

In diff case assembly line the overall PPM, should down to 60PPM as shown in the below graph. Here from the past financial year the parts per million is 1488 and by implementing all the improvements in quality by implementing poka yoke in the line PPM come down.

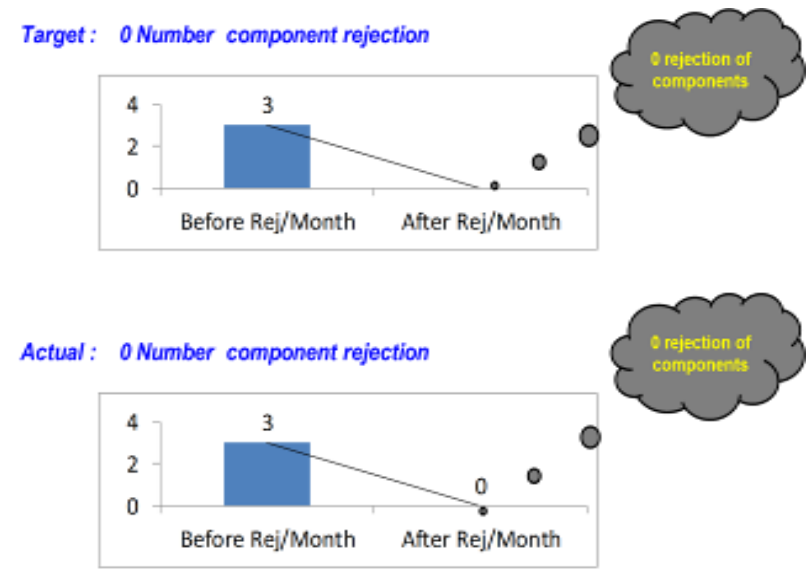

Fig 6.2 Rejection

In this process around $50 \%$ of the non-value added activities are converted in to value added activities and the required table is shown below

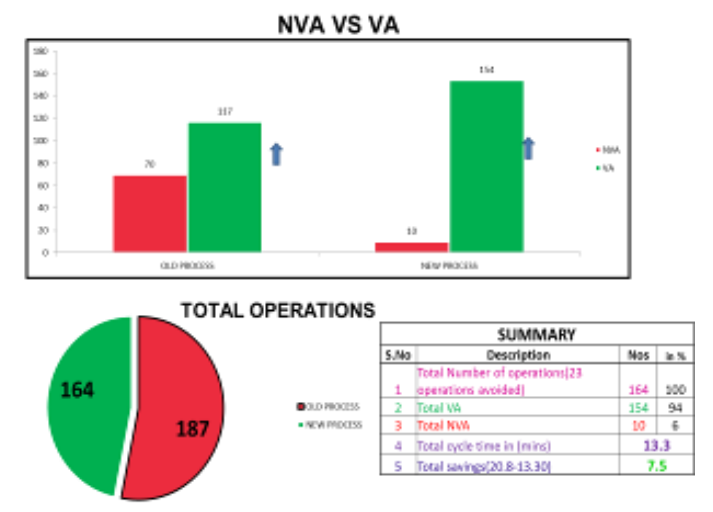

Fig 6.3 NVA vs VA

In this process, the overall cycle time is 1248 seconds, for that we have set the target of 624 seconds but as the end result we achieved as the savings of 800 seconds. This shows the result of $95 \%$ of cycle time savings from the existing process, this is clearly shown in the below figure.

cycle time improvement:

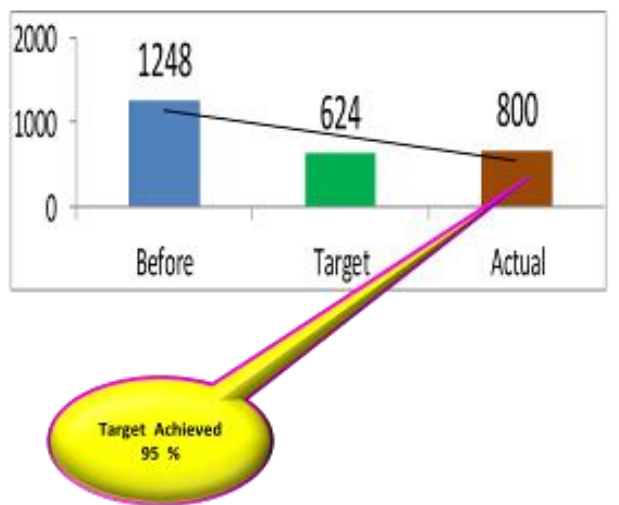

Fig 6.4 Cycle time improvement

In the below table, the overall result achieved by this project, through Inventory, Man movement, space utilization and quality improvement as shown. In words the Inventory is reduced from 20 tractors to 5 tractors in line side. Man movement reduced from 2 meters per assembly to 1 meter for sub assembly that is 50\% reduction. Quality improvement is achieved by $20 \%$.



Fig 7.1 Overall result

VII. CONCLUSION

In this project, Productivity of diff-case sub assembly has been improved and defect in the sub assembly has been reduced through various analyses and testing. Based on this improvements like cycle time reduction, man power elimination, non-value added activities has been reduced, defects has been completely eliminated and brought to zero, through this projects many kaizen were implemented which benefited the organization more so, I sincerely thank Mr.Premkumar for supporting me throughout the project. As a whole I thank both the TAFE and KALASALINGAM UNIVERSITY for providing me such a great opportunity where I can improve myself and make organization to gain benefit

\section{REFERENCE}

1. Jaiprakash Bhamu, Kuldip Singh Sangwan, (2014) "Lean manufacturing: literature review and research issues", International Journal of Operations \& Production Management, Vol. 34 Issue: 7, pp.876-940, https://doi.org/10.1108/IJOPM-08-2012-0315.

2. Peter Hines, Nick Rich, Ann Esain, (1999) "Value stream mapping: A distribution industry application", Benchmarking: An International $\begin{array}{llll}\text { Journal, } & \text { Vol. } & 6 & \text { Issue: }\end{array}$ pp.60-77, https://doi.org/10.1108/14635779910258157

3. I.I. Rozenfeld, Corrosion Inhibitors, McGraw-Hill, New York, 1981, p 182.

4. N. Hckermain, H. Kaesche, J. Electrochem. Soc. 105 (1958) 191.

5. E. Schumann, C. Sarioglu, J. R. Blachere, F. S. Pettit, G. H. Meier, Oxid. Metals 53, 259 (2000)

6. Shaul Salomon, Gideon Avigad, Robin C. Purshouse and Peter J. Fleming, Gearbox design for uncertain load requirements using active robust optimization, Engineering Optimization, 48, 4,(652), (2016).

7. T. N. Goh, Future- Proofing Six Sigma, Quality and Reliability Engineering International, 30, 8, (1389-1392), (2013).

8. Ronald J.M.M. Does and Jeroen De Mast, Six Sigma Method, Wiley StatsRef: Statistics Reference Online, (1-2), (2015).

9. Ravi S. Reosekar and Sanjay D. Pohekar, Six Sigma methodology: a structured review, International Journal of Lean Six Sigma, 10.1108/IJLSS-12-2013-0059, 5, 4, (392-422), (2014).Crossref

10. Ricardo Pires de Souza, Hélio Roberto Hékis, Lucas AmbrósioBezerraOliveira, JamersonViegasQueiroz, Fernanda Cristina Barbosa Pereira Queiroz and Ricardo Alexsandro de

Published By:

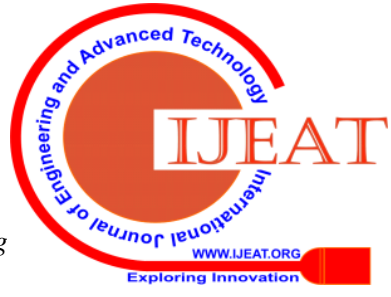

